\title{
Professor PhDr. Gabriela Petrová, CSc.
}

\author{
Erich Petlák*
}

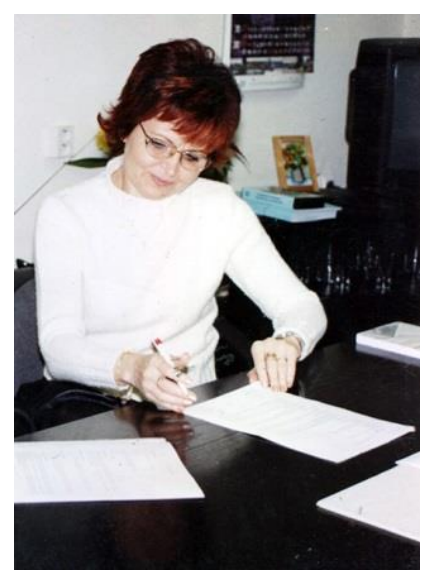

In april (April 10, 2016), Professor PhDr. Gabriela Petrová, CSc., an outstanding Slovak pedagogue working at the Faculty of Education at Constantine the Philosopher University in Nitra, celebrated her life anniversary. We presume that thanks to her professional and organizational skills and her presentations at many professional events, but also her membership in many professional committees, hundreds of our teachers know her. Those who know her for a longer period of time know her as a vital personality with a desire to always organize something and to collaborate with others.

The words above say a lot about the life path of Professor Petrová. In her case, being a pedagogue is not a coincidence, a view in her curriculum vitae shows that her first steps after finishing elementary school lead to the Secondary Pedagogical School in Turčianske Teplice. During her studies at the secondary

* Erich Petlák, Catholic University in Ružomberok, Ružomberok, Slovakia; erich.petlak@ku.sk 


\section{Acta Technologica Dubnicae \\ volume 6, 2016, issue 1}

pedagogical school, she developed her pedagogical skills and then she continued her studies at the Faculty of Arts of Comenius University in Bratislava in the field of pedagogy. After her successful graduation in 1979, she started working at the position of an administrative officer at the Department of Education of the Faculty of Education in Nitra, which has become a part of Constantine the Philosopher University in Nitra.

Professor Gabriela Petrová has always been not only a responsible teacher but a diligent and creative personality, too. Before I start the description of the rich list of her activities which will follow after these words, I find it important to emphasize that since her arrival at the faculty till today, she has always deserved respect and recognition. Besides having a highly demanding job, her students have remained at the first place for her. And that is one of those aspects that make Professor Petrová so popular among students but also her colleagues at her home university and other universities both in Slovakia and the Czech Republic.

For Professor Petrová her attempts to provide highly professional education of students are characteristic. She has always cared about her professional development. The years in which she earned her scientific and pedagogical degrees are a proof of her serious and systematic approach. In 1980, it was the degree of PhDr., in 1988, after finishing a 5-year external program of study in Brno, she defended her candidate dissertation thesis "Application of the Principle of Consistency in University Training of Primary School Teachers" at the Faculty of Arts of Jan Evangelista Purkyně University in Ústí nad Labem and she earned the scientific degree of CSc. In 2001, she defended her habilitation thesis "Teacher Training for Differentiated Educational Practice" and gave her habilitation presentation "Increasing the Efficiency of the Educational Process by Means of a Humanistic Approach to Students" at the Constantine the Philosopher University in Nitra. In 2006, she was awarded the degree of Professor in Pedagogy by the President of the Slovak Republic. Professor Petrová has produced a long list of publications, but also her educational work (including the annual student competition Student Scientific Professional and Artistic Activity) is very important. She keeps showing her students what pedagogical optimism and humanism are. It is worth to mention that the professional development of Professor Petrová indicates her focus on the field of pedeutology in connection with many didactic aspects.

Taking into consideration the character of this paper, only a selection of her activities in this field is offered. In her portfolio, e.g. three monographs, two university textbooks, several chapters in domestic and foreign monographs and university textbooks, approximately 180 studies and articles in domestic and foreign journals, 19 conference contributions in Slovakia and equally 19 conference contributions abroad are included. Her professional work, 


\section{Acta Technologica Dubnicae \\ volume 6, 2016, issue 1}

communication with the world, exchanging experiences and publication abroad are needless to mention. It is admirable that that Professor Petrová has participated in 25 stays abroad - Cordoba, Freiburg, Katowice, Madrid, Kyjev, Lueven, Tielburg, Reykjavik and others - where she represented Slovak pedagogy abroad, but also gained new knowledge for her school and her students. Also for this informal work she is exceptionally popular with her students and doctoral students, to whom she gives advice and whom she helps and guides.

Such a rich list of activities indicates a very active and creative personality who must be involved also in other than only pedagogical didactical activities. It is natural that creativity, commitment but also a good orientation in the field of her interest were noticed by her colleagues at the faculty. They found Professor Petrova the person whose abilities can help the department, the faculty and last but not least, the whole university. So the department administration officer became the deputy head of the department and, after being awarded the degree of Professor, she was elected the Dean of the Faculty of Education. She was the Dean for two office periods from 2002 to 2010. Those are the years when the faculty achieved significant success. It is not a subjective opinion but the point view of the pedagogues according to whom the mentioned years are perceived as really progressive for the overall development of the Faculty of Education of Constantine the Philosopher University in Nitra and Professor Petrová contributed to it to a great extent. It is probably Professor Petrová's destiny to coordinate, lead and manage something. Since her period of office ended, she has worked as the Head of the Department of Education.

The list of her activities would not be complete if I did not mention her activities in the scientific boards of several universities in Slovakia but also in the Czech Republic, e.g. Charles University in Prague, University of Ostrava and Institute of Lifelong Learning in Brno.

Professor Petrová's energy and abilities are admirable. Taking a look in her portfolio we can find out that currently she is the member of three editorial boards and, at the same time, many professional committees and panels. For instance, she is a member of the Accreditation Committee - an advisory body of the Slovak Republic's Government, chairperson of the Accreditation Commission of the Ministry of Education, Science, Research and Sport of the Slovak Republic for further education of educational and professional staff, a member of accreditation teams for several fields, a member of professional committees for pedagogy in Nitra, Bratislava, Banská Bystrica, Trnava and other universities. This all is only an incomplete list of her activities as she is also a member of habilitation and inauguration committees, etc. 


\section{Acta Technologica Dubnicae \\ volume 6, 2016, issue 1}

Professor Petrová's awards are the logical outcome of her activities. The Great Medal of St. Gorazd in 2016 and The Small Medal of St. Gorazd in 2014 are among the most valuable ones, but she has also received several awards of the Minister of Education of the Slovak Republic, and gold and silver medals of universities both in Slovakia and in the Czech Republic - Bratislava, Nitra, Banská Bystrica, Brno, etc.

The picture of Professor Petrová would be incomplete without a look into her private life. Her two sons, having their mother as a role model, completed their university studies in the fields of economy and management. Both of them work at interesting job positions - one of them is the Editor in Chief of a recognized professional journal and the other one is a PR manager. It is natural that Professor Petrová, as a loving mother, is proud of them and often speaks about them. I would like to add that Professor Petrová can probably manage work not only at the faculty and the department, but also in her household as her husband's job is not an easy one - he is a doctor.

I am sure there are many things that I have not mentioned but I must not forget to mention the human aspect of the personality of Professor PhDr. Gabriela Petrová, CSc. We have spent together 40 years of work that have united us and our colleagues as a younger team. We had to face "anger", experienced many pleasing but also problematic situations, but it belongs to everyday work life. What I would like to say is that turning back in time, it was a different era when we helped and supported each other, gave advice and were pleased by the success of our colleagues. I am glad to have the opportunity to proudly recall those times and to mention the workplace to the development of which Professor Petrová has contributed a lot. Probably not only me but there is more of us who wonder what is the source of her energy, enthusiasm and, maybe, also sacrifice for others. Professor Petrová follows Gordon B. Hinckley's quote "Without hard work, nothing grows but weeds."

What else to add? Dear Professor Petrová, do not let the weeds grow. We believe that you can do it and we will have the opportunity to meet your work for many years. For doing so, we wish you good prosperity, and a lot of family, personal and professional satisfaction. We wish you all the best. 